УДК 551.8; DOI 10.30970/gpc.2020.1.3204

\author{
ВИВЧЕНІСТЬ ГОЛОЦЕНОВОГО ЕТАПУ ФОРМУВАННЯ \\ ПЕРЕДКАРПАТСЬКОЇ ЧАСТИНИ ДОЛИНИ ДНІСТРА \\ Андрій Яцишин ${ }^{1}$, Пьотр Гембіца ${ }^{2}$ \\ ${ }^{1}$ Львівський національний університет імені Івана Франка, \\ andrij_jacyshyn@ukr.net; orcid.org/0000-0002-3114-3042; \\ ${ }^{2}$ Instytut Archeologii, Uniwersytet Rzeszowski, \\ piotrgebica@wp.pl; orcid.org/0000-0001-8109-267X
}

Анотація. Схарактеризовано головні етапи вивчення заплави - першої надзаплавної тераси Дністра в межах передкарпатського фрагмента долини річки, проаналізовано тематику досліджень і здобуті результати. Встановлено, що на усіх етапах досліджень проводили, передусім, грунтовні аналізи морфологічних і морфометричних параметрів заплави - першої надзаплавної тераси Дністра, будови і фаціальної структури їхніх алювіальних нагромаджень, а також палінологічні аналізи захоронених в алювіальних товщах біогенних нагромаджень. Результати, здобуті під час проведення палінологічних аналізів, використано для датування ерозійно-акумулятивних циклів та реконструкції фізико-географічних умов часу формування заплави - першої надзаплавної тераси Дністра. На останньому етапі досліджень також активно проведено радіовуглецеві датування похованих в алювіальних товщах біогенних відкладів.

Зібраний на перших двох етапах досліджень масив геолого-геоморфологічної інформації дав змогу встановити, що, по-перше, впродовж голоцену в долині Дністра сформувались перша надзаплавна тераса i заплава. Першу надзаплавну терасу, перевищення якої над руслом Дністра сягають 4-6 м, можна розглядати і як високу заплаву, яка часто вкривається високими паводками. Тераса акумулятивна, проте, на відміну від усіх інших терас Дністра, позбавлена лесового покриву. В розрізі іï нагромаджень відслонюються відклади алювію руслової фації, збудованої галечниками, а зверху вони перекриті алювієм заплавної фації, складеної пісками, супісками і суглинками. Загальна потужність алювію сягає 9-10 м і мало змінюється униз за течією Дністра. Крім, хіба, Верхньодністерської улоговини, де потужність алювію зростає до 10-18 м, а в його розрізі з'являються прошарки торфу. Заплава піднімається на 4-5 м над руслом Дністра. Вона збудована алювієм руслової фації, у складі переважають піщаногалечникові товщі, місцями перекриті піщаними або суглинистими відкладами заплавної фації.

По-друге, в передкарпатській частині долини Дністра перебіг флювіальних морфолітогенетичних процесів регулювали не тільки кліматичні зміни і неотектонічні рухи, а й господарська діяльність людини. Доволі масштабний вплив людини, який проявлявся у регулюванні русел рік, спорудженні протиповеневих валів, меліоративних каналів тощо, відбувався упродовж XIX-XX ст.

Результати новіших геоморфологічних досліджень, проведених у межах досліджуваного фрагмента долини річки, палінологічних і радіовуглецевих датувань, дали змогу суттєво удосконалити уявлення про морфологію, будову та історію формування заплави - першої надзаплавної тераси Дністра. Зокрема, нами встановлено, що акумуляція алювію першої надзаплавної тераси, перевищення якої над руслом Дністра сягають 5,5-6,5 (7) м, розпочалось у фінальній частині пізнього плейстоцену (бьолінгу (?)-алереду) (13 000-11 000 років тому(GI-1)). Імовірно, перша надзаплавна тераса розчленована меандруючим руслом Дністра в молодшому дріасі (11 00010000 років тому (GS-1)). Алювіальні відклади, якими виповнені ці крупні палеомеандри, досі добре збереглись і часто відслонюються в уступах першої тераси.

Подальший розвиток системи заплави - першої надзаплавної тераси Дністра відбувався в декілька етапів, датованих завершенням бореалу, початком атлантику, 
А. Яцишин, П. Гембіца Вивченість голоценового етапу...

кінцем атлантику, суббореалом, початком субатлантику, а також упродовж V-VI, X-XII i XIV-XVI ст. Виявлені етапи корелюють 3 циклами зволоження клімату і зростання флювіальної активності русел рік (фазами повеней). Унаслідок активізації ерозійноакумулятивної діяльності Дністра сформувались два-три голоценові рівні заплави, висотою до 4-5 м і 3-4 м.

Перші сліди діяльності людини у межах вивченого фрагмента долини Дністра датують суббореалом і фіксують за наявністю у спорово-пилкових діаграмах профілів Майнич (Верхньодністерська улоговина) і Цвітова (Галицько-Букачівська улоговина) пилку збіжжя.

Ключові слова: долина Дністра; заплава; перша надзаплавна тераса; алювій; фази повеней; алеред; молодший дріас; голоцен.

\section{STUDY OF THE HOLOCENE STAGE OF FORMATION OF THE DNIESTER VALLEY IN THE EASTERN CARPATHIAN FORELAND Andriy Yatsyshyn ${ }^{1}$, Piotr Gembitsa ${ }^{2}$ \\ ${ }^{1}$ Ivan Franko National University of Lviv; \\ ${ }^{2}$ Institute of Archeology of the Rzeszow University, Rzeszow, Poland}

Abstract. The article describes the main stages of studying of the floodplain and the first floodplain terrace of the Dniester river within the Eastern Carpathian Foreland fragment of the valley, and evaluates the results of existing studies. It is discovered that during all the stages of the research morphological and morphometric parameters of the floodplain and the first floodplain terrace of the Dniester river, morphology and facie structures of the alluvial accumulations, as well as palynological analyses of biogenic accumulations buried in an alluvial series are performed. The results obtained during the palynological analyzes are used to date the erosion-accumulation cycles and to reconstruct the physical-geographical conditions of the time of the floodplain and the first floodplain formation of the Dniester terrace. The radiocarbon dating of biogenic sediments buried in alluvial series is also actively conducted at the last stage of the research.

The array of geological and geomorphological information collected at the first two stages of research made it possible to establish that, first, the first floodplain terrace and floodplain were formed during the Holocene in the Dniester Valley. The first floodplain terrace (the height of which reaches 4-6 m above the Dniester riverbed) can be considered as a high floodplain which is often covered by high floods. The terrace is accumulative, but unlike all other terraces of the Dniester it is devoid of the loess cover. In the cross-sections of its accumulations the deposits of the alluvium of the channel facies builted of pebbles are exposed and covered with the alluvium of the floodplain facies composed of sands, sandy loams and loams. The total thickness of alluvium reaches 9-10 $\mathrm{m}$ and it doesn't varysignificantly downstream of the Dniester. Except the Upper Dniester basin, where the thickness of the alluvium increases to 10$18 \mathrm{~m}$, and the layers of peat are found. The floodplain is $4-5 \mathrm{~m}$ above the Dniester riverbed and is built of alluvium of the channel facies, dominated by sand and pebble series. In someplaces floodplain is covered with sandy or loamy deposits of floodplain facies.

Secondly, in the Eastern Carpathian Foreland part of the Dniester valley the course of fluvial morpholitogenetic processes was regulated not only by climatic changes and neotectonic movements, but also by human economic activity. During the XIX-XX centuries especially large-scale human influence was on the Dniester riverbeds by construction of flood ramparts, reclamation canals, etc.

The results of recent geomorphological research conducted within the studied fragment of the river valley particularly palynological and radiocarbon dating have significantly improved the idea of morphology, structure and history of floodplain formation and the first floodplain terrace of the Dniester. The research revealed that the accumulation of alluvium of the first 
А. Яцишин, П. Гембіца Вивченість голоценового етапу..

floodplain terrace which is above the Dniester riverbed reaches 5,5-6,5 (7) $\mathrm{m}$ and started to develop in the late Pleistocene (Bølling-Allerød interstadial) (13 000-11 000 years ago (GI-1)). Presumably in the early Dryas (11000-10 000 years ago (GS-1)), the first floodplain terrace was dissected by the meandering channel of the Dniester. The alluvial deposits that fill these large paleomeanders are still well preserved and are often exposed in the ledges of the first terrace.

The further development of the floodplain and first floodplain terrace of the Dniester river was taking place in several stages such as the end of the boreal, the beginning of the atlantic, the end of the atlantic, subboreal, the beginning of the subatlantic, as well as during V-VI, X-XII and XIV-XVIcenturies. These stages are identified in correlation with the cycles of humidification of the climate and the growth of fluvial activity of riverbeds (flood phases). As a result of the intensification of erosion-accumulation activity of the Dniester the two - three levels of Holocene floodplain were formed up to 4-5 $\mathrm{m}$ and 3-4 $\mathrm{m}$ high.

The first traces of human activity within the studied fragment of the Dniester valley were dated by subboreal and recorded by the presence of grain pollen in the spore-pollen diagrams of Mainych (Upper Dniester Basin) and Tsvitova (Galician-Bukachiv Basin) sections.

Key words: Dniester valley; floodplain; the first floodplain terrace; alluvium; phases of floods; Allerød; early Dryas; Holocene.

Вступ. Під час тривалих і різнопланових досліджень заплави - першої надзаплавної тераси Дністра зібрано та узагальнено інформацію про їхні морфологічні i морфометричні параметри, будову i фаціальну структуру алювіальних нагромаджень, встановлено час розгортання ерозійноакумулятивних циклів, ідентифіковано фактори формування заплави - першої надзаплавної тераси, тобто розкриті ключові характеристики заплави - першої надзаплавної тераси Дністра: вік, генезис і морфологію. У зв'язку з цим може скластись уявлення, що, нібито, голоценова історія формування передкарпатської частини долини Дністра досконало вивчена.

Однак під час проведення новіших досліджень виявлено низку невідомих раніше рис будови та історії формування заплави - першої надзаплавної тераси Дністра. Зокрема, колективом німецьких фахівців-природничників поблизу Миколаєва описано сім голоценових терас, що значно більше, ніж виокремлювали автори інших схем будови долини річки. Зібрані нами матеріали засвідчують, що нагромадження алювіальних відкладів руслової фації першої надзаплавної тераси розпочалось у фінальній частині пізнього плейстоцену (бьолінгу (?)-алереду (GI-1)). У голоцені ця тераса активно надбудовувалась алювієм заплавної фації. Тобто вік першої надзаплавної тераси пізньоплейстоценово-голоценовий.

Окрім того, досі дискусії точаться щодо питання будови заплави і першої надзаплавної тераси Дністра в межах Верхньодністерської i СтрийськоЖидачівської улоговин. Зокрема, так i не узгоджені уявлення про час формування потужних (до 20-25 м) алювіально-флювіогляціальних товщ, якими виповнена Верхньодністерська улоговина (Демедюк і Сокуров, 1974; Цись, 1962). Автори Д. Афремов, І. Гофштейн, Г. Раскатов заперечували участь флювіогляціальних відкладів у цій товщі (Афремов, 1969; Гофштейн, 1958; Гофштейн, 1962; Раскатов, 1954). Зазначимо, що В. Палієнко взагалі пропонувала розглядати цю товщу як одновікову пачку відкладів, сформованих упродовж голоцену (Палиенко, 1965). Також слабко вивченими є долини 
А. Яцишин, П. Гембіца Вивченість голоценового етапу..

карпатських i, передусім, подільських приток Дністра. Отже, аналіз голоценової історії формування передкарпатської частини долини Дністра ще не завершений.

Історія досліджень. Дослідженням голоценового етапу формування передкарпатської частини долини Дністра притаманна добре виражена циклічність. Чітко простежуються три етапи доволі активного вивчення флювіальних морфолітогенетичних процесів голоценового віку: перший - до Другої світової війни; другий - 60-70-ті роки минулого століття; третій розпочався на рубежі дев'яностих-двохтисячних років і триває досі.

Перший $\boldsymbol{i}$ найтриваліший етап характеризується формуванням початкових уявлень про морфологію заплави - першої надзаплавної тераси Дністра, збором малакологічних та палінологічних даних, які використовували для датування ерозійно-акумулятивних циклів. Тогочасні дослідження асоціюються з іменами
А. Ломницького,
С. Рудницького,
Г. Тессейре та
M. Костинюка (Рудницький, 1907; $\quad$ Kostyniuk, 1938; $\quad$ Łomnicki, 1900; $\quad$ Teisseyre, 1935; Teisseyre, 1938). Найгрунтовнішими серед них є геоморфологічні дослідження $\Gamma$. Тессейре та палінологічні аналізи $М$. Костинюка. Зокрема, Г. Тессейре голоценові тераси об'єднував у дві групи:

1) заплавні тераси, які формуються досі, збудовані галечниками і пісками, а їхні відносні відмітки не перевищують 2 м;

2) надзаплавні тераси, перевищення яких коливаються в межах 2-6 м, зрідка понад 6 м. Складені вони в нижній частині пісками і галечниками, зверху перекриті супісками і пісками. В товщі алювію часто трапляються уламки похованих дерев, рослинний детрит. На зволожених ділянках терас розвиваються торфи (Teisseyre, 1938).

На підставі зібраної у відслоненні 3-5-метрової тераси Стривігору поблизу с. Бісковичі колекції малакофауни Г. Тессейре дійшов висновку, що клімат часу формування тераси не відрізнявся від сучасного, або ледь відрізнявся (Teisseyre, 1938). Цю терасу Г. Тессейре співставляв 3 4-метровою терасою Дністра, описаною Ю. Полянським на подільській ділянці долини, яка формувалась у кліматичний оптимум голоцену (атлантик, можливо суббореал). Розчленування тераси відбулось упродовж субатлантику.

На підставі опрацювання органогенних відкладів, розкритих в днищі долини Вишні поблизу Рудок, М. Костинюк реконструював історію розвитку голоценової рослинності північної частини Передкарпаття (Kostyniuk, 1938). Автор окреслив три етапи розвитку рослинності, які повністю корелюють 3 етапами, виявленими та схарактеризованими іншими палінологами для сусідніх регіонів Польщі.

Двом наступним етапам досліджень заплави - першої надзаплавної тераси Дністра притаманні такі спільні риси:

1) проведення активних морфологічних аналізів;

2) вивчення будови нагромаджень заплави - першої надзаплавної тераси, у тому числі фаціальної структури алювію;

3) палінологічні дослідження розвинених у розрізах алювію заплави - першої надзаплавної тераси Дністра біогенних нагромаджень i залучення здобутих даних до датування ерозійно-акумулятивних циклів та реконструкції фізикогеографічних умов часу формування заплави - першої надзаплавної тераси Дністра. 
А. Яцишин, П. Гембіца Вивченість голоценового етапу..

Другий eman. Упродовж 60-70-х років минулого століття активні геологогеоморфологічні дослідження заплави - першої надзаплавної тераси Дністра проводили А. Артюшенко, Д. Афремов, І. Гофштейн, М. Демедюк, В. Палієнко та інші (Артюшенко і Палиенко, 1968; Афремов, 1969; Афремов, 1970; Воропай, Куниця і Левицький, 1975; Гофштейн, 1958; Гофштейн, 1962; Демедюк, 1974; Демедюк і Сокуров, 1974; Палиенко, 1965; Палиенко, 1969; Палиенко, 1974; Петренко, Третяк і Ковалюх, 1987; Черевко, 1967). Першість у цих дослідженнях належить І. Гофштейну (Гофштейн, 1958; Гофштейн, 1962), який сформулював положення, що практично в незмінному вигляді використовували згодом інші науковці. За його спостереженнями, впродовж голоцену в долині Дністра сформувались перша надзаплавна тераса і заплава. Першу надзаплавну терасу I. Гофштейн розглядав і як високу заплаву, яку часто вкривають високі паводки. Ïї перевищення над руслом Дністра сягають 4-6 м, а ширина змінюється від 1,5 км до декількох кілометрів. Тераса акумулятивна, проте на відміну від усіх інших терас Дністра, вона позбавлена лесового покриву. Розріз нагромаджень тераси в типовому вигляді дво- або тришаровий: на корінному ложі залягають нагромадження алювію руслової фації, збудовані галечниками; зверху вони перекриті алювієм заплавної фації, складеної пісками, супісками і суглинками. Загальна потужність алювію першої тераси сягає 9-10 м і мало змінюється униз за течією, крім, хіба, Верхньодністерської улоговини, де потужність алювію зростає до 10-18 м, а в його розрізі з'являються прошарки торфу. Формування улоговини, на думку І. Гофштейна, розпочалось у плейстоцені, а впродовж голоцену вона зазнавала невеликого опускання. Заплава, що піднімається на 0,52 м над руслом Дністра, збудована алювієм, в складі якого переважають піщаногалечникові товщі, місцями перекриті піщаним або суглинистим грунтом.

Інша знакова дослідниця геоморфології долини Дністра - В. Палієнко - у повздовжньому профілі заплави річки виокремила три ділянки, які відрізняються своїми морфологічними параметрами i будовою товщі алювіальних нагромаджень (Палиенко, 1965). Перша ділянка розташована між Старим Самбором і Гординею, друга - між Гординею і гирлом Колодниці, а третя - нижче гирла Колодниці (у межах південно-західної окраїни Східноєвропейської платформи).

На першій ділянці заплава Дністра двостороння симетрична висотою 2-3 м і шириною до 1-2 км (Палиенко, 1965). У розрізі алювію виокремлено дві фації руслову і заплавну, контакт між якими зафіксовано на 0,7-1,0 м вище меженного урізу води в руслі Дністра. Загальна потужність алювію сягає 6-10 м.

Нижче Гордині (в межах Верхньодністерської улоговини) морфологія i будова заплави змінюються. Вона представлена широкою (до 8,9-9,0 км) заболоченою рівниною, розчленованою старицями, руслами. Окрім руслової і заплавної фацій, вагому роль відіграють також нагромадження старичної фації. Щодо дискусії про вік пухких нагромаджень, які виповнюють Верхньодністерську улоговину, то ця товща, на думку В. Палієнко, $\epsilon$ одновіковою, нижню частину якої варто розглядати як руслову фацію алювію, а верхню - як заплавну (Палиенко, 1965). Підвищену потужність алювію, розташування контакту між русловою і заплавною фаціями під урізом води в руслі Дністра, а також дрібнозернистий склад алювію руслової фації дослідниця 
А. Яцишин, П. Гембіца Вивченість голоценового етапу...

пояснює зміною напряму тектонічних рухів: новіші опускання в ранньому голоцені змінились підняттями на сучасному етапі розвитку улоговини.

Нижче гирла Колодниці заплава звужується, іiі ширина змінюється з 0,5 до 2,5-3,0 км, а перевищення над руслом Дністра сягають 4,0-4,5 м (Палиенко, 1965). У розрізі нагромаджень заплави відслонюються відклади руслової, заплавної і старичної фацій. Загальна потужність алювію сягає 14-15 м. Контакт між русловою і заплавною фаціями зафіксовано на висоті $0,5-0,7$ м над урізом води.

Досліджуючи заплаву Дністра, В. Палієнко також з'ясувала, що розподіл фацій алювію, його потужності i морфологічні параметри заплави підпорядковані сучасному структурному плану Передкарпатського прогину, передусім неотектонічній активності окремих ділянок території, яку перетинає річка, зокрема в районі перетину локальних структур (Палиенко, 1969). Окрім структурного плану території Передкарпаття, важливу роль у формуванні особливостей будови алювію і морфології низьких терас також відіграє гідрологічний фактор (Палиенко, 1969).

Узагальнюючи здобуті відомості про типи алювію, його риси будови i сумарний вплив на них гідрологічного фактора, диференційованого характеру голоценових рухів земної кори, у повздовжньому профілі Дністра (в напрямі від витоків до устя) В. Палієнко виокремила три ділянки, які послідовно змінюють одна одну: гірську - від витоків до Старого Самбора; передгірсько-рівнинну - від Старого Самбора до Розвадова; рівнинну - нижче Розвадова (Палиенко, 1974).

Потужність передгірсько-рівнинного типу алювію сягає 10-14 м. Характерною рисою цього типу алювію $\epsilon$, по-перше, неповнота його фаціального профілю, передусім групи заплавних відкладів (Палиенко, 1974). По-друге, йому притаманна незначна потужність нагромаджень заплавної фації, крім Верхньодністерської улоговини, яка на початку голоцену зазнала опускань. Завдяки цьому нагромадилась значна товща заплавного алювію, яка навіть перевищує потужність товщі алювію руслової фації.

Рівнинний тип відкладів характеризується повним розвитком усіх фаціальних груп алювію майже на всій довжині рівної частини долини Дністра, крім іiі каньйонної частини, де 3 групи заплавних фацій розвинена, передусім, прирічкова (Палиенко, 1974). Потужність рівнинного типу нагромаджень між Розвадовом і Нижнім досягає 15-25 м.

За спостереженнями Д. Афремова, окрім кліматичних флуктуацій та структурного плану території, важливу роль у формуванні особливостей морфометрії низьких терас Дністра також відігравав антропогенний фактор (Афремов, 1969). Учений встановив, що перевищення високої заплави Дністра поступово зростають від 3-4 м між Карпатами і Самбором до 5-7 м між Самбором і Гординею. Нижче Гордині і до р. Колодниця ії висота в минулому зменшувалась і для прируслової заплави досягала 2,5-3,3 м. Однак упродовж 1900-1914 років проводили регулювання русла Дністра, спрямлення меандрів, що скоротило первинну довжину русла майже вдвічі. Внаслідок цього, вважає учений, відбулось поглиблення русла на 2-3 м і висота заплави зросла.

Висновки Д. Афремова щодо морфології, будови заплави - першої надзаплавної тераси Дністра практично ідентичні результатам, здобутим 
А. Яцишин, П. Гембіца Вивченість голоценового етапу..

I. Гофштейном. Зокрема, Д. Афремов також розглядає першу надзаплавну терасу як зародковий рівень, близький до заплави (Афремов, 1969).

Під час вивчення заплави - першої надзаплавної тераси Дністра М. Демедюк сконцентрував свою увагу, передусім, на аналізі літологічних особливостей голоценових алювіальних галечників (Демедюк, 1974). Учений встановив, що галечники, які репрезентують нагромадження руслової фації, збудовані конгломератами, гравелітами, пісковиками, алевролітами, кварцом, кременистими i карбонатними породами (Демедюк, 1974). Головним компонентом є різнозернисті карпатські пісковики. Спостерігається загальне покращення обкатаності матеріалу в міру віддалення від гір, яке відбувається, передусім, за рахунок збільшення кількості добре- i середньообкатаного матеріалу i зменшення погано обкатаного (Демедюк, 1974). Зміни гранулометричного складу галечників мають складний розподіл. Зокрема, на ділянці між Карпатами і Самбором спостерігається зменшення крупності матеріалу (Демедюк, 1974). У межах Верхньодністерської улоговини прируслові відмілини часто збудовані піском. Нижче за течією Дністра в розподіл крупності матеріалу корективи вносять карпатські притоки, які постачають у русло Дністра помітно грубший матеріал, аніж він транспортує. Отож нижче гирла карпатських приток Дністра спостерігається зростання вмісту грубих галечників.

Важливим складовим елементом тогочасних досліджень заплави - першої надзаплавної тераси Дністра $є$ палінологічні аналізи органогенних відкладів, виявлених у розрізах їхніх нагромаджень (Артюшенко і Палиенко, 1968; Афремов, 1970; Черевко, 1967). Проведений М. Черевко палінологічний аналіз органогенних відкладів, розкритих свердловинами у прибортових частинах Верхньодністерської улоговини, засвідчив, що їхній пилковий спектр майже цілковито подібний до пилкової діаграми М. Костинюка (Черевко, 1967). Зокрема, ранній голоцен характеризується суворим континентальним кліматом, який сприяв поширенню лісу, з переважанням у його складі сосни і берези, а 3 часом 3'явились ялина та вільха. Середній голоцен характеризується розповсюдженням ялиново-широколистяних лісів. У пізньому голоцені основною лісоутворювальною породою вважають ялицю та бук. На завершенні голоцену спостерігається зменшення кількості пилку ялини та ялиці, а також збільшення відсотка вмісту пилку сосни, берези. Окрім того, в спорово-пилкових спектрах діаграм спостерігається зростання загальної кількості трав'янистого пилку, зокрема злакових та різнотрав'я. Такі зміни відсоткового співвідношення між окремими породами М. Черевко пояснює господарською діяльністю людини, зокрема зменшенням залісненості території.

Автори О. Артюшенко, Д. Афремов на підставі палінологічних аналізів розрізів алювію, закладених у межах Верхньодністерської улоговини, дійшли висновку, що біогенні нагромадження у розрізах алювію акумулювались упродовж усього голоцену (Артюшенко і Палиенко, 1968; Афремов, 1970). Водночас значна частина заплавного алювію, який місцями зберігся в тиловій частині заплави, нагромадилась у ранньому і середньому голоцені.

На основі аналізу похованих голоценових грунтів, розкритих у розрізах нагромаджень заплави, Л. Воропай, М. Куниця і В. Левицький реконструювали фізико-географічні умови часу іiі формування (Воропай та ін., 1975). Здобуті 
А. Яцишин, П. Гембіца Вивченість голоценового етапу...

ними результати засвідчили, що розташована у межах Верхньодністерської улоговини заплава Дністра пережила низку етапів розвитку:

1) заболочена заплава 3 ослабленим алювіальним процесом i різнотравно-злаковими лучними ландшафтами;

2) суха заплава 3 активним алювіальним процесом і ландшафтами чагарниково-суходільних лугів;

3) сучасна висока заплава 3 активним осадонагромадженням i ландшафтами пасовищно-дегресійних лугів.

Чергування в розрізах нагромаджень заплави алювіальних горизонтів i похованих грунтів засвідчує, на думку авторів дослідження, неодноразові різкі зміни режимів розвитку заплави в голоцені. Зміна потужності, літології і генезису алювіальних товщ відображає істотні зміни коливальних рухів, фізикогеографічних умов та інтенсивності руслових процесів під час різних субаквальних фаз.

Tpemiŭ eman досліджень голоценової історії формування передкарпатської частини долини Дністра, який розпочався на рубежі дев'яностих-двохтисячних років, найперше асоціюється 3 дослідженнями двох колективів науковців: німецького і польсько-українського.

Німецький колектив фахівців-природничників у долині Дністра поблизу Миколаєва виокремив сім голоценових терас (Huhmann et al., 2004). Найстарша 3 них датована пребореалом. В історії формування долини Дністра науковці виокремили декілька переломних подій. Перша 3 них проявилась у пізньому льодовиковому періоді, ще до формування голоценових терас, i характеризувалась трансформацією русла річки з багаторукавного на меандровий (Huhmann et al., 2004).

Друга подія припадає на залізний вік і на період великого переселення народів. Вона характеризується змінами русла 3 меандрового на багаторукавне (Huhmann et al., 2004). Причина цих змін криється не тільки в кліматичних змінах, а також пов'язана зі зростанням впливу людини, передусім активним в останні 170 років, коли розпочали роботи з регулювання русла Дністра.

Третя подія - прогнозована - розпочнеться, за розрахунками науковців, у недалекому майбутньому. Вона проявлятиметься у втручанні людини в гідрологічний режим Дністра, передусім під час гідротехнічного будівництва, що зумовить закріплення русла Дністра, посилення глибинної ерозії та поступове звільнення заплави від повеней (Huhmann et al., 2004).

Підсумовуючи результати досліджень, німецькі учені наголошували на тому, що в долині Дністра процеси терасоформування регулюються загальними кліматичними коливаннями, проте щораз більшого значення набуває втручання людини. Обидва чинники більшою або меншою мірою можуть активно впливати на початок i тривалість змін річкового та долинного режиму. Взаємно посилюючись або послаблюючись, комплекси чинників флювіальної системи (стік, похил та ін.), території (геологічна будова, морфологія долини та ін.) та умови зовнішнього середовища (клімат, рослинність, людина та ін.) несуть відповідальність за форму і масштаби динамічних змін ріки.

Значно триваліші і масштабніші дослідження заплави - першої надзаплавної тераси Дністра, його карпатських приток виконав польсько-український колектив науковців (Калинович, 2000; Калинович і Хармата, 2001; Калинович і 
А. Яцишин, П. Гембіца Вивченість голоценового етапу...

Яцишин, 2001; Чумак, 2013; Чумак, 2015; Яцишин, 2001; Яцишин, 2002; Яцишин та ін., 2010; Яцишин та ін., 2011; Budek et al., 2000; Budek, Starkel \& Jacyšyn, 2006; Gębica et al., 2007; Gębica et al., 2008; Gębica et al., 2011; Gębica et al., 2013; Gębica et al., 2013; Gębica \& Jacyszyn, 2014; Gębica et al., 2016; Harmata et al., 2006; Harmata et al., 2006; Harmata, Madeja \& Kołaczek, 2013; Harmata, Madeja \& Kołaczek, 2013; Jacyšyn et al., 2006; Kalinovyč, Budek \& Starkel, 2006; Starkel et al., 2009). 31998 р і досі їхніми дослідженнями охоплені частини долин Дністра і його карпатських приток, які відображені на рис. 1.

Матеріали і методи досліджень. Під час польових досліджень нами опрацьовано понад сорок розрізів алювіальних нагромаджень заплави - першої надзаплавної тераси Дністра, його карпатських приток, а також пробурено понад сорок свердловин. 3 описаних відслонень та кернів свердловин відібрано зразки на визначення гранулометричного складу алювію, моноліти для аналізу мікроморфології викопних грунтів, зразки біогенних відкладів на палінологічні аналізи, а також фрагменти похованих в алювіальних товщах дерев на радіовуглецеві датування.

Визначення гранулометричного складу алювію лазерним і ситовим методами виконано М. Бонєцьким у Грунтовій лабораторії інституту географії i просторової економіки Ягеллонського університету в Кракові, А. Будек з Відділу досліджень геосередовища Польської академії наук у Кракові.

Мікроморфологічні аналізи шліфів викопних грунтів проведені А. Будек у Відділі досліджень геосередовища Польської академії наук у Кракові.

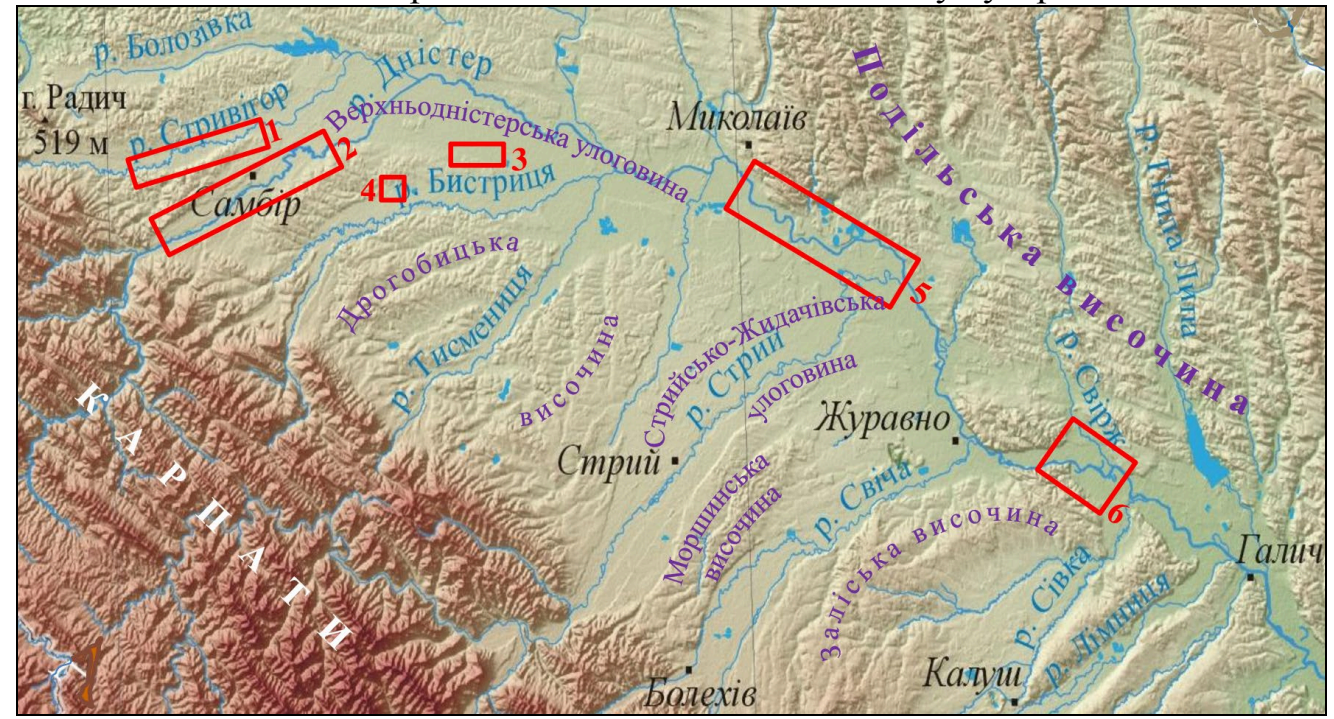

Рис. 1. Досліджені фрагменти заплави-першої надзаплавної тераси Дністра, його карпатських приток:

1 - в долині Стривігору (розрізи Муроване II, Засадки I і II, Чаплі, Гуманець I і II, Язи I-III, Заріччя-село, Заріччя-кар'єр та керни 16 свердловин); 2 - в долині Дністра (розрізи Созань, Торгановичі, Бережниця, Хатки, Самбір I i II, Кружики II i IV, Гординя I і II); 3 - в долині Дністра (розріз Майнич I-VI); 4 - в долині Бистриці-Підбузької (розріз Озерне I-III (Лука)); 5 - в долині ДністраСтрию (розрізи Надітичі I і II, Київець, Черниця, Жидачів-Місто I і II, Жидачів- 
А. Яцишин, П. Гембіца Вивченість голоценового етапу...

Дачі I-IV та керни 12 свердловин); 6 - в долині Дністра (розрізи Козарі I-V, Цвітова, Лука та керни 11 свердловин)

Fig. 1. Study area of the floodplain and of the first floodplain terrace of the Dniester, with its Carpathian tributaries:

1 - in the Strivigor valley (Murovane II, Zasadky I and II, Chapli, Humanets I and II, Yazy I-III, Zarichchia village, Zarichchia-quarry sections and drill core of 16 boreholes); 2 - in the valley of the Dniester (Sozan, Torganovichi, Berezhnytsia, Khatky, Sambir I and II, Kruzhyky II and IV, Gordynia I and II sections); 3 - in the Dniester valley (Mainich I-VI sections); 4 - in the valley of Bystritsa-Pidbuzka (Ozerne I-III (Luka) sections); 5 - in the Dniester-Stryi valley (Naditichi I and II, Kyivets, Chernytsia, Zhydachiv-city I and II, Zhydachiv-summerhouse I-IV sections and drill core of 12 boreholes); 6 - in the Dniester valley (Kozari I-V, Tsvitova, Luka sections and drill core of 11 boreholes)

Палінологічні аналізи виконані Н. Калинович з біологічного факультету Львівського національного університету імені Івана Франка, Н. Чумак 3 географічного факультету Київського національного університету імені Тараса Шевченка, К. Щепанком, К. Харматою і Я. Мадея 3 Відділу ботаніки Ягеллонського університету в Кракові, П. Колачеком з Відділу географічних і геологічних наук Університету імені Адама Міцкевича в Познані.

Радіовуглецеві датування виконані М. Ковалюхом 3 Київської радіовуглецевої лабораторії, М. Кромпцем з Гірничо-металургійної академії у Кракові і А. Паздур з Радіовуглецевої лабораторії Інституту фізики Шльонського технічного університету в Глівіцах.

На підставі зібраної під час опрацювання відслонень та аналізу кернів свердловин інформації про будову та вік алювіальних нагромаджень заплави першої надзаплавної тераси Дністра, його карпатських приток побудовано серію поперечних геолого-геоморфологічних профілів.

Результати. Результати виконаних геоморфологічних досліджень, палінологічних і радіовуглецевих датувань дали змогу в межах досліджуваного фрагмента долини Дністра ідентифікувати алювіальні нагромадження однієї пізньоплейстоценово-голоценової першої надзаплавної тераси, двох - трьох голоценових рівнів заплави, а також різновікові лінзи старичного алювію, вкладені в алювіальні товщі заплави, першої надзаплавної тераси Дністра, Стривігору, Стрию і деяких інших рік. Нагромадження алювію першої надзаплавної тераси Дністра, його карпатських приток розпочалось у фінальній частині пізнього плейстоцену (бьолінгу (?)-алереду, GI-1) (Budek et al., 2006; Gębica i in., 2008; Gębica i in., 2011; Gębica i in., 2013; Gębica et al., 2013; Gębica i in., 2014; Gębica et al. 2016; Harmata et al., 2006; Starkel et al., 2009). Тогочасний алювій виповнює поховані під кількаметровою товщею алювію голоценового віку палеорусла, які розкриті в долинах Стривігору (розрізи Заріччя-Село, Заріччя-Кар'єр), Дністра (розріз Надітичі), Стрию (розріз Жидачів-Місто).

У молодшому дріасі перша надзаплавна тераса Дністра, його карпатських приток була розчленована руслами рік з притаманними їм великими меандрами, які досі збереглись у маргінальних частинах днищ річкових долин. Алювіальні відклади, якими виповнені ці крупні палеомеандри, розкриті в долині БистриціПідбузької (розріз Озерне), Дністра (розрізи Букачівці, Лука і Козарі). 
Волога фаза бореалу (8500-7800 років тому) зафіксована в розрізі алювію 10метрової першої надзаплавної тераси Дністра Торгановичі (район Старого Самбора), а також у Верхньодністерській улоговині (розріз Майнич), де один 3 палеомеандрів Дністра відшнурований від русла річки близько 7600 років тому (Harmata et al., 2006; Jacyšyn et al., 2006). Лінза алювію, датована 86007700 років тому, виявлена і в межах Галицько-Букачівської улоговини - околиці Букачівців (Huhmann et al., 2004).

Зволоження клімату i часті повені наприкінці атлантику (59005400 років тому) спричинили врізання русла Дністра вглиб у межах ГалицькоБукачівської улоговини (розрізи Цвітова, Лука і Козарі), а також міграцію русла річки по літералі й акумуляцію пісків близько 5400 років тому, які перекрили біогенні відклади у стариці, розвиненій поблизу с. Майнич (Верхньодністерська улоговина) (Harmata et al., 2006; Harmata et al., 2013; Harmata et al., 2013). Упродовж атлантику також нагромаджувались алювіальні відклади, якими виповнені палеоврізи в долині р. Стривігор (розріз Заріччя-Кар'єр, палеовріз p. Ясениці), та алювіальні нагромадження Дністра в розрізах Черниця, ЖидачівМісто (Стрийсько-Жидачівська улоговина) (Starkel et al., 2009, Gębica et al., 2013).

Час між 4400-3800 роками тому (суббореал) був вологим, що засвідчують підвищення рівня вод у торфовищах (старицях), розкритих у розрізах Майнич (Верхньодністерська улоговина) і Цвітова (Галицько-Букачівська улоговина) (Harmata et al., 2006; Harmata et al., 2013). Проте в інших розрізах алювію терас Дністра тогочасні фази повеней чітко не зафіксовано. Алювій суббореального віку, який нагромаджувався в інтервалі 3500-3000 років тому, ми також розкрили в розрізах Заріччя-Кар'єр, Чаплі, Язи (усі розташовані в долині Стривігору), Жидачів-Місто (Стрийсько-Жидачівська улоговина) і Лука, Козарі (Галицько-Букачівська улоговина) (Gębica i in., 2008; Gębica i in., 2014; Gębica et al, 2016; Starkel et al., 2009; Harmata et al, 2013). Цьому етапу формування долини Дністра притаманні активні міграції русла Дністра i посилення акумуляції алювію заплавної фації. Окрім того, наявність у спорово-пилкових діаграмах профілів Майнич (Верхньодністерська улоговина) і Цвітова (ГалицькоБукачівська улоговина) пилку збіжжя засвідчує, що люди вже могли активно освоювати тераси, розвинені в днищі долини Дністра. Це означає, що вже в суббореалі в долині Дністра могла сформуватись тераса, яку за особливостями перебігу в iі межах флювіальних морфолітогенетичних процесів можна ідентифікувати як першу надзаплавну.

Наступний етап активізації ерозійно-акумулятивних процесів припав на початок субатлантику (між 2300-2100 роками тому). Алювій субатлантичного віку розкритий у розрізах Засадки, Заріччя (долина Стривігору), Созань і Бережниця (долина Дністра), Надітичі, Київець, Жидачів-Дачі (СтрийськоЖидачівська улоговина) і Лука, Козарі (Галицько-Букачівська улоговина) (Gębica i in., 2007; Gębica i in., 2008; Gębica i in., 2011; Gębica et al., 2013; Gębica i in., 2013; Gębica i in., 2014; Gębica et al., 2016; Harmata et al., 2013). Фаза активної акумуляції стовбурів дерев, виявлених у перелічених розрізах, тривала між 2100-1700 роками тому i, очевидно, пов'язана 3 інтервенцією людини в долину Дністра в римський час. 
А. Яцишин, П. Гембіца Вивченість голоценового етапу...

Етап V-VI ст. збігається 3 початком вологої фази клімату (14001230 років тому), а також відчутним антропогенним впливом (міграції людей) (Gębica i in., 2008; Gębica i in., 2011; Gębica et al., 2013; Gębica i in., 2013; Gębica i in., 2014; Gębica et al., 2016; Harmata et al., 2013; Harmata et al., 2013). Тогочасні алювіальні нагромадження розкриті в долині Стривігору i СтрийськоЖидачівській улоговині (розріз Жидачів-Дачі).

Фази повеней X-XII і XIV-XVI ст. фіксують зростання діяльності людини (Budek i in., 2000; Gębica i in., 2007; Gębica i in., 2013; Gębica et al., 2013; Gębica i in., 2014; Gębica et al., 2016; Jacyšyn et al., 2006). Водночас повені першої половини ХІ ст. синхронізуються 3 фазою зволоження клімату (960900 років тому), яка передувала середньовічному потеплінню клімату. Нагромаджений упродовж $\mathrm{X}-\mathrm{XII}$ ст. алювій розкритий у розрізах Кружики 1 (Верхньодністерська улоговина) i Жидачів-Дачі (Стрийсько-Жидачівська улоговина). Активне освоєння людиною передкарпатського басейну Дністра впродовж XIV-XVIст. відобразилось у посиленні акумуляції алювію і захороненні в його товщі дерев, нині розкритих у долині Стрию (околиці м. Жидачів, датовано у проміжку між $490 \pm 35$ і $290 \pm 30$ років тому), а також у долині Дністра в розрізі Кружики (датовано $400 \pm 35$ років тому).

Зростання частоти повеней упродовж XI-XVI ст., окрім антропогенного чинника, також мають і природний компонент, адже збігаються з похолоданням і зволоженням клімату на початку малої льодовикової епохи (550-390 років тому).

Упродовж XIX-XX ст. простежено масштабний безпосередній вплив людини на гідрологічний режим Дністра. Зокрема, відбулося регулювання русла річки, спорудження протиповеневих валів, меліоративних каналів тощо.

Проведеними дослідженнями також підтверджено, що на зміни морфології заплави - першої надзаплавної тераси Дністра, будови їхніх алювіальних нагромаджень, окрім кліматичних змін і діяльності людини, впливали неотектонічні рухи (Gębica et al., 2016). На це вказує факт розташування ложа алювіальних нагромаджень заплав, перших надзаплавних терас Дністра, Стривігору і Бистриці-Підбузької, розвинених на прилеглих до Карпат ділянках їхніх долин вище меженного урізу води в руслах рік.

Сумарний ефект кліматичних змін, діяльності людини, неотектонічних рухів також проявляється в змінах у поздовжньому профілі долини Дністра ширини поясу заплави - першої надзаплавної тераси, кількості розвинених рівнів заплави, будові і віку їхніх алювіальних нагромаджень, змінах ухилу русла річки і поверхні заплави - першої надзаплавної тераси (рис. 2).

На ділянках долин Дністра, Стривігору, Бистриці-Підбузької, розвинених між уступом Карпат і Верхньодністерською улоговиною, ширина поясу їхніх заплав - перших надзаплавних терас коливається в межах 0,5-1,5 км, а ухил поверхонь сягає 1-2\%. 3 просуванням униз за течіями Дністра, Стривігору, БистриціПідбузької і віддаленням від Карпат підошви алювіальних нагромаджень їхніх заплав - перших надзаплавних терас поступово занурюються під меженні урізи води у руслах цих річок. Ерозійно-акумулятивні процеси у цих частинах долин найактивніше розгортались упродовж таких інтервалів: 3500-3000 та 22001700 років тому, а також V-VII i XIV-XVII ст. (Budek i in., 2000; Budek et al., 2006; Gębica i in., 2007; Gębica i in., 2008; Gębica i in., 2011; Gębica 
А. Яцишин, П. Гембіца Вивченість голоценового етапу..

et al., 2013; Gębica i in., 2013; Gębica i in., 2014; Gębica et al., 2016; Starkel et al., 2009).

У межах Верхньодністерської і Стрийсько-Жидачівської улоговин пояс заплав - перших надзаплавних терас Дністра і Стрию помітно розширюється, місцями до 4-8 км, а ухил їхніх поверхонь зменшується до $1 \%$. Відносні перевищення заплав, перших надзаплавних терас зростають унаслідок активізації глибинної ерозії, зокрема, у пізньому плейстоцені, а також надбудов заплав перших надзаплавних терас Дністра і Стрию алювієм заплавної фації, найактивніших упродовж раннього голоцену. Окрім того, розріз нагромаджень першої надзаплавної тераси Дністра, розвиненої у межах Верхньодністерської улоговини, активно нарощували біогенні відклади (торф), передусім упродовж ео- та мезоголоцену.

У Стрийсько-Жидачівській улоговині розвиток поясу заплав - перших надзаплавних терас Дністра i Стрию насамперед пов'язаний 3 активними міграціями русел рік по літералі. У розрізах їхніх нагромаджень розкрито складнопобудовану товщу алювію, акумульовану у шість етапів: в пізньому плейстоцені (бьолінгу (?)-алереді (12000-11000 років тому)), на завершенні атлантику (6000-5400 років тому), суббореалі (3500-2800), упродовж римського часу (2100-1700 років тому), в ранньому середньовіччі (V-VII і X-XII ст.) та впродовж малої льодовикової епохи (XIV-XVI ст.).

У межах Журавненського прориву ширина поясу пізньогляціал-голоценових терас Дністра звужується до 1,5-2,0 км, а місцями навіть до 1,0 км. У розрізах їхніх нагромаджень простежується омолодження алювію, пов'язане 3 домінуванням процесів активної переробки старших товщ алювію.

У Галицько-Букачівській улоговині розвиток поясу пізньогляціалголоценових терас пов'язаний з активними міграціями русла Дністра по літералі. У смузі поширення його першої надзаплавної тераси - заплави алювій датовано молодшим дріасом (11000-10300 років тому), початком атлантику (8700-7800), завершенням атлантику - початком суббореалу (6000-5400 років тому), римським часом, раннім середньовіччям, малою льодовиковою епохою й останніми 150 роками.

Обговорення і висновки. На підставі змін морфологічних параметрів i будови товщі алювіальних нагромаджень у поздовжньому профілі першої надзаплавної тераси - заплави Дністра можна виокремити три ділянки. Виявлені зміни морфологічних параметрів заплави, розподілу фацій алювію, його потужностей підпорядковані сучасному структурному плану Передкарпатського прогину, передусім неотектонічній активності окремих ділянок території, яку перетинає річка, зокрема в районі перетину локальних структур. Окрім структурного плану території Передкарпаття, важливу роль у формуванні особливостей будови алювію i морфології низьких терас відіграють гідрологічний та антропогенний фактори.

Розріз нагромаджень першої надзаплавної тераси в типовому вигляді дво- або тришаровий: на корінному ложі залягають нагромадження алювію руслової фації, які збудовані галечниками; зверху вони перекриті алювієм заплавної фацій, складеної пісками, супісками і суглинками. 


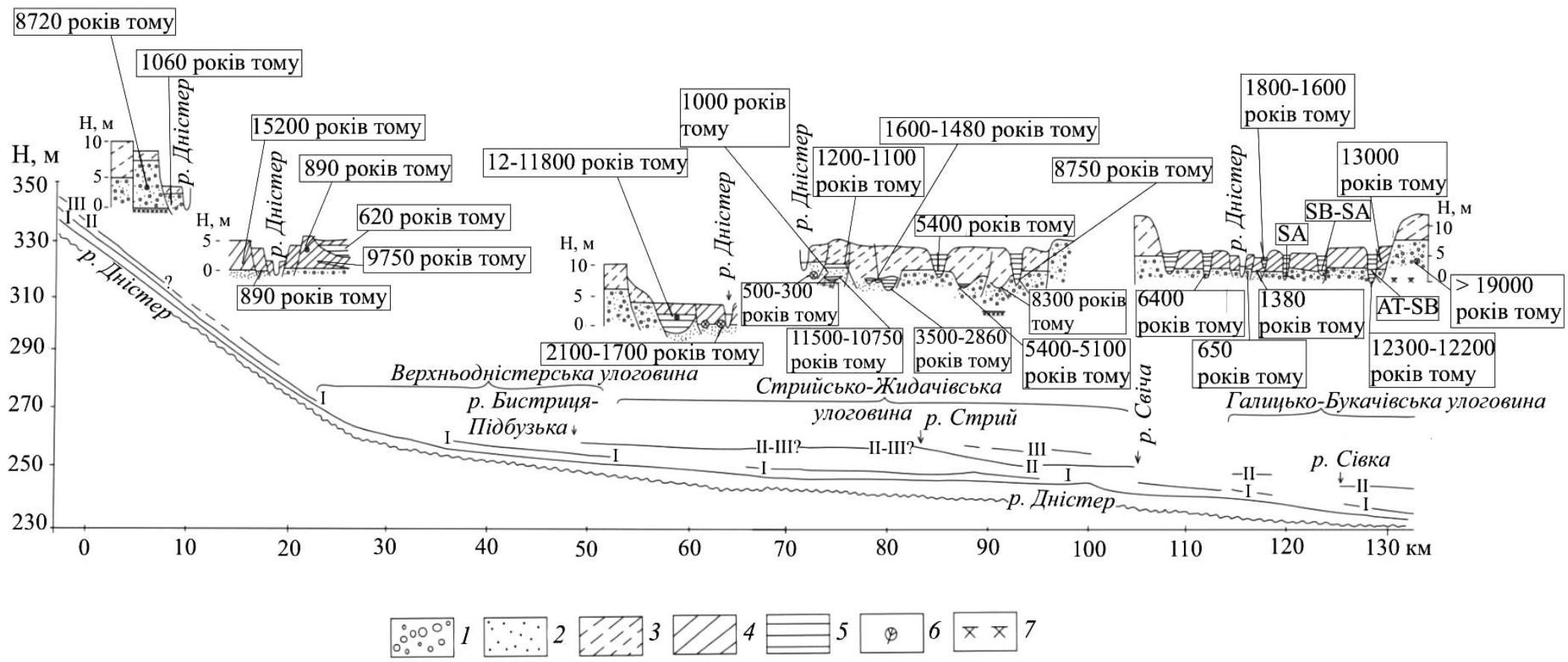

Рис. 2. Зміни будови пізньоплейстоцен-голоценової першої надзаплавної тераси і голоценової заплави Дністра в поздовжньому профілі його долини (Gębica et al., 2016): 1 - гравійно-гальково-валунний матеріал; 2 - піски; 3 - супіски; 4 суглинки; 5 - глини; 6 - поховані дерева; 7 - ложе алювію (корінні породи)

Fig. 2. Changes in the structure of the Late Pleistocene-Holocene first floodplain terrace and the Holocene floodplain of the Dniester river in the longitudinal profile of its valley (Gębica et al., 2016): 1 - gravel-pebble-boulder material; 2 - sand; 3 - sandy loam; 4 - loam; 5 - clay; 6 - buried trees;(fossil trees); 7 - bed of alluvium (bedrocks) 
У розрізі заплави відслонюється руслова фація алювію, в складі якого переважають піщано-галечникові товщі, місцями перекриті піщаними або суглинистими нагромадженнями заплавної фації.

Галечники складені конгломератами, гравелітами, пісковиками, алевролітами, кременистими і карбонатними породами. Часто трапляється кварц. Головним компонентом $\epsilon$ різнозернисті карпатські пісковики. Спостерігається загальне покращення обкатаності матеріалу в міру віддалення від гір, яке відбувається, здебільшого, за рахунок збільшення кількості добре- i середньообкатаного матеріалу і зменшення погано обкатаного.

Зміни гранулометричного складу галечників мають складний розподіл. У розподіл крупності матеріалу корективи вносять карпатські притоки Дністра, які постачають в русло річки помітно грубший матеріал, аніж транспортує власне Дністер. Отож нижче гирла карпатських приток Дністра спостерігається зростання вмісту грубих галечників.

Отримані з розрізів алювіальних нагромаджень першої надзаплавної тераси, заплави Дністра палінологічні дані, результати радіовуглецевих датувань дали змогу ідентифікувати алювіальні нагромадження однієї пізноплейстоценголоценової першої надзаплавної тераси, двох - трьох голоценових рівнів заплави та лінзи алювію, якими виповнені поширені в межах заплави - першої надзаплавної тераси різновікові палеомеандри. Окрім товщ алювію, продатованих алередом (12000-11000 років тому), молодшим дріасом (11000$10300)$, кінцем бореалу - початком атлантику (8700-7800), завершенням атлантику (6000-5400), суббореалу (4200-2800), початком субатлантику (між 2300-1700 роками тому), середнім субатлантиком (між 1880-1470 роками тому) $\mathrm{i}$ V-VII ст., у смузі поширення заплави - першої надзаплавної тераси також виявлено лінзи, вкладки старичного алювію, датованого X-XII, XIV-XVI ст. і останніми 150-200 роками.

Подяки. Дослідження фінансоване Національним фондом досліджень України i $\epsilon$ частиною проекту "Розвиток палеокріогенних процесів $\mathrm{y}$ плейстоценовій лесово-грунтовій серії України: інженерно-геологічний, грунтовий, кліматичний, природоохоронний аспекти” (реєстраційний номер 2020.02/0165).

\section{СПИСОК ВИКОРИСТАНОЇ ЛІТЕРАТУРИ}

Артюшенко А. О геологическом строении и возрасте пойменных отложений бассейна верхнего Днестра в Предкарпатье / Артюшенко А., Палиенко В. // Геол. журнал. - Киев. - 1968. - Т. 28. - Вып. 6.- С. 65-71.

Афремов Д. Антропогенные влияния на формирование продольного профиля р. Днестр / Афремов Д. // Изв. АН СССР. Сер. географ. № 3. - Москва, 1969. C. $39-43$.

Афремов Д. Возраст пойменного аллювия Днестра по данным палинологического анализа / Афремов Д. // Вест. Москов. ун-та. География. Москва. - 1970. - № 3. - С. 102-105.

Воропай Л. Поховані голоценові грунти заплав середнього Придністров'я та їх палеогеографічне значення / Воропай Л., Куниця М., Левицький В. // Фіз. географія та геоморфологія. - Київ. - 1975. - Вип. 14. - С. 103-112. 
Гофштейн И. К истории долины верхнего Днестра / Гофштейн И. // Докл. АН СССР. - Москва. - 1958. - Т. 120. - № 1. - С. 159-161.

Гофштейн I. Неотектоніка і морфогенез Верхнього Придністров’я / Гофштейн I. - Київ : Вид-во АН УРСР, 1962. - 131 с.

Демедюк Н. Литологические особенности голоценовых аллювиальных галечников Предкарпатья / Демедюк Н. // Материалы по четвертичному периоду Украины. К IX Конгрессу INQUA. - Киев, 1974. - С. 228-246.

Демедюк Н. Аномально-высокие мощности аллювия в предгорной части долины Днестра и использование их при поисках солей / Демедюк Н., Сокуров С. // Материалы по четвертичному периоду Украины. К IX Конгрессу INQUA. Киев, 1974. - С. 259-265.

Калинович Н. Палінологічне дослідження розвитку рослинного покриву Верхньодністровської рівнини в голоцені / Калинович Н. // Науковий вісник Українського держ. лісотехніч. ун-ту. - Львів. - 2000. - Вип. 10.3. - С. 69-74.

Калинович Н. Реконструкція історії рослинності Верхньодністровської рівнини в голоцені на основі палінологічного аналізу торфових відкладів / Калинович Н., Хармата К. // Вісник Львів. ун-ту. Серія біолог. - Львів. - 2001. - Вип. 27. - С. 78-88.

Калинович Н. Антропогенні зміни рослинності Північно-західного Передкарпаття в голоцені // Калинович Н., Яцишин А. // Науковий вісник УжНУ. Сер. Біологія. - Ужгород. - 2001. - Вип. 10. - С. 45-48.

Палиенко В. Влияние новейших движений земной коры на строение голоценовой террасы Верхнего Днестра / Палиенко В. // Материалы по четвертичному периоду Украины. К VII Конгрессу INQUA. - Киев, 1965. - С. 262-269.

Палиенко В. О некоторых особенностях геологического строения пойменных террас Предкарпатья, обусловленных неотектоническими движениями / Палиенко В. // Материалы по четвертичному периоду Украины. К VIII Конгрессу INQUA. - Киев, 1969. - С. 198-209.

Палиенко В. О типах голоценового аллювия долины Днестра / Палиенко В. // Материалы по четвертичному периоду Украины. К IX Конгрессу INQUA. Киев, 1974. - С. 247-258.

Петренко Л. Геохронология формирования аллювиальных отложений р. Днестр в позднем голоцене // Петренко Л., Третяк П., Ковалюх Н. // Стратиграфия и корреляция морских и континентальных отложений Украины. - Киев, 1987. C. $78-84$.

Раскатов Г. К вопросу о древнечетвертичных оледенениях западных областей Украины / Раскатов Г. // Труды геологич. факультета Воронежск. гос. ун-та. Воронеж. - 1954. - Т. 31. - С. 107-111.

Рудницький С. Знадоби до морфології підкарпатського сточища Дністра / Рудницький С. // Зб. матем.-природописн. лікар. секції НТШ. - 1907. - Т. 11. C. $1-80$.

Цись П. Геоморфологія УРСР / Цись П. - Львів : Вид-во Львів. ун-ту, 1962. $223 \mathrm{c}$.

Черевко М. Матеріали до історії рослинності Прикарпаття в післяльодовиковий період / Черевко М. // Вісник Львів. ун-ту. Серія біолог. - Львів. - 1967. Вип. 3. - С. 102-111. 
Чумак Н. Палеогеографічні умови Пригорганського Передкарпаття у голоцені (за палінологічними даними) : автореф. дис. канд. географ. наук: 11.00.04. геоморфологія і палеогеографія. - Київ, 2013. - 18 с.

Чумак Н. Реконструкція рослинного покриву Пригорганського Передкарпаття у пізньольодовиків'ї (за палінологічними даними торфовища Підлужжя) / Чумак Н. // Вісник Львів. ун-ту. Серія геогр. Вип. 49. - Львів, 2015. - С. $333-$ 340.

Яцишин А. Геоморфологічна будова долини Дністра у межах Передкарпаття : автореф. дис. канд. географ. наук : 11.00 .04 - геоморфологія і палеогеографія. - Львів, 2001. - 18 с.

Яцишин А. Нові дані про будову Верхньодністровської улоговини / Яцишин А. // Регіональні екологічні проблеми : зб. наук. праць Київського національного університету імені Тараса Шевченка. - Київ, 2002. - С. 251-252.

Яцишин А. Антропогенові відклади північної частини Верхньодністерської улоговини / Яцишин А., Богуцький А., Дмитрук Р., Плотніков А. // Фіз. географія та геоморфологія. - Київ, 2010. - С. 177-188.

Яцишин А. Етапи морфогенезу північно-західної частини долини Дністра / Яцишин А., Богуцький А., Голуб Б., Ланчонт М., Томенюк О. // Гляціал і перигляціал Українського Передкарпаття : зб. наук. праць (до XVII українсько-польського семінару. Самбір, 15-18 вересня 2011 р). - Львів, 2011. - C. 26-61.

Budek A. Aluwia holoceńskie i ich relacja do faz osadniczych na Wysoczyźnie Samborskiej i w Kotlinie Górnego Dniestru / Budek A., Jacyszyn A., Starkel L. // Neolit i poczatki epoki brazu w Karpatach Polskich : materialy z sesji naukowej (Krosno, 14-15 grudnia 2000 r.). - Kraków, 2000.-. P. 241-249.

Budek A. Strvjaž River valley / Budek A., Starkel L., Jacyšyn A. // Environment and man at the Carpathian foreland in the upper Dnister catchment from Neolithic to early mediaeval period / ed. by K. Harmata, J. Machnik, L. Starkel. - Krakow, 2006. - P. 52-65.

Gębica P. Znaczenie kopalnych pni drzew i profili torfowych dla stratygrafii aluwiów i faz powodzi w dorzeczu górnego Dniestru / Gębica P., Jacyšyn A., Krąpiec M. i in. // Krajobrazy dolin rzecznych : materiały polsko-ukraińskiej konferencij naukowej (IX seminarium krajobrazowe, 26-29.05.2007, Czerniowce-Sosnowiec-Czerniowce). - Czerniowce, 2007. - S. 22-23.

Gębica P. Nowe wyniki badań nad stratygrafia aluwiów i holoceńską ewolucją doliny Strwiąża (Zachodnia Ukraina) / Gębica P., Budek A., Starkel L. i in. // Prace Komisji Paleogeografii Cwartorzędu PAU. - 2008. - T. 6. - S. 93-103.

Gębica P. Ewolucja doliny Strwiąża w póżnym glacjale i holocenie na przedpolu Wschodnich Karpat (Zachodnia Ukraina) / Gębica P., Starkel L., Jacyszyn A. i in. // Гляціал і перигляціал Українського Передкарпаття : зб. наук. праць (до XVII укр.-пол. семінару. Самбір, 15-18 вересня 2011 р). - Львів, 2011. - С. 106-116.

Gębica P. Medieval accumulation in the Upper Dniester river valley: The role of human impact and climate change in the Carpathian Foreland / Gębica P., Starkel L., Jacyszyn A., Krąpiec M. // Quaternary International. - 2013. - Vol. 293. - P. 207-218.

Gębica P. Ewolucja doliny Stryja i Dniestru w kotlinie Stryjsko-Źydaczowskiej w póżnym vistulianiee i holocenie / Gębica P., Jacyszyn A., Budek A., Czumak N. // 
Лесовий покрив Північного Причорномор'я : зб. наук. праць (до XVIII укр.пол. семінару. Роксолани, 8-13 вересня 2013 р). - Люблін, 2013. - С. 241-257.

Gębica P. Młodoczwartorzędowa ewolucja doliny Dniestru i Stryja w Kotlinie Stryjsko-Źydaczowskiej (Wschodnie Przedkarpacie) / Gębica P., Jacyszyn A. // Krajobrazy młodoglacjalne ich morfogeneza teraźniejszość przyszlość : X Zjazd Geomorfologów Polskich (Torun, 16-19 wrzesnia 2014 r.). - Toruń, 2014. - S. 4142.

Gębica P. Stratigraphy of alluvia and phases of the Holocene floods in the valleys of the Eastern Carpathians foreland / Gębica P., Jacyszyn A., Krąpiec M. et al. // Quaternary International. - 2016. - Vol. 415. - P. 55-66.

Harmata K. Mire and the Dnister valley near Majnyč / Harmata K., Kalinovyč N., Budek A. et al. // Environment and man at the Carpathian foreland in the upper Dnister catchment from Neolithic to early mediaeval period / ed. by K. Harmata, J. Machnik, L. Starkel. - Krakow, 2006. - P. 32-43.

Harmata K. Environmental changes during the Holocene / Harmata K., Kalinovyč N., Budek A. et al. // Environment and man at the Carpathian foreland in the upper Dnister catchment from Neolithic to early mediaeval period / ed. by K. Harmata, J. Machnik, L. Starkel. - Krakow, 2006. - P. 66-81.

Harmata K. The locality Luka - palynological analysis / Harmata K., Madeja J., Kołaczek P. // Prace Komisji Prehistorii Karpat PAU: Natural Environment and man on the Upper Dnister - region of the Halyč-Bukačivci Basin - in Prehistory and Early Mediaeval Period / ed. by K. Harmata, J. Machnik, M. Rybicka. Kraków, 2013. - Vol. 6. - P. 42-49.

Harmata K. The locality Cvitova - palynological analysis / Harmata K., Szczepanek K., Cywa K. et al. // Prace Komisji Prehistorii Karpat PAU: Natural Environment and man on the Upper Dnister - region of the Halyč-Bukačivci Basin - in Prehistory and Early Mediaeval Period / ed. by K. Harmata, J. Machnik, M. Rybicka. - Kraków, 2013. - Vol. 6. - P. 49-56.

Huhmann M. Late guaternary landscape evolution of the upper Dnister valley, western Ukraine / Huhmann M., Kremenetski K. V., Hiller A., Brückner H. // Paleogeography, Paleoclimatology, Paleoecology. - 2004. - Vol. 209. - P. 51-71.

Jacyšyn A. Dnister River valley / Jacyšyn A., Budek A., Kalinovyč N., Starkel L. // Environment and man at the Carpathian foreland in the upper Dnister catchment from Neolithic to early mediaeval period / ed. by K. Harmata, J. Machnik, L. Starkel. - Krakow, 2006. - P. 21-31.

Kalinovyč N. Peat-bog in the Bystrycia River valley near Ozerne (Now Łuka) / Kalinovyč N., Budek A., Starkel L. // Environment and man at the Carpathian foreland in the upper Dnister catchment from Neolithic to early mediaeval period / ed. by K. Harmata, J. Machnik, L. Starkel. - Krakow, 2006. - P. 44-51.

Kostyniuk M. Analiza pylkowa dwuch torfowisk w okolicy Rudek i Sambora / Kostyniuk M. // Kosmos. - 1938. - T. 63. - Z. 3. - P. 393-412.

Łomnicki A. Atlas geologiczny Galicyi. Tekst do zeszytu 12. - Kraków, 1900. - 80 s.

Starkel L. Evolution of the lower section of the Strvyaž riwer valley during the Holocene (foreland of the Eastern Carpathians) / Starkel L., Gębica P., Budek A. et al. // Studia Geomorphologica Carpatho-Balcanica. - 2009. - Vol. 43. - S. 5-37.

Teisseyre H. Czwartorzęd na predgórgu arkusza Stary Sambor / Teisseyre H. // Rocz. Pol. tow. Geol. 1935. - T. 8. - P. 67-81. 
Teisseyre H. Czwartorzęd na predhórgy arkuszy Sambor i Dobromil / Teisseyre H. // Rocz. Pol. Tow. Geol. - 1938. - T. 13. - S. 31-81.

\section{REFERENCES}

Artiushenko A., Palienko V. (1968). O geologicheskom stroienie i vozraste poimennykh otlozhenii baseina verkhnioho Dnestra v Predcarpatie [Geological structure and the age of the floodplain sediments of the upper Dniester basin in Eastern Carpathian Foreland]. In Geol. gornal., 28, 6, 65-71. (In Russian).

Afremov D. (1969). Antropogennyie vliianiia na formirovanie prodolnoho profilia r. Dnestr [Anthropogenicin fluences on the formation of the longitudinal profile of the Dniester River]. In Izv. AN USSR. Ser. geograph., 3, 39-43. (In Russian).

Afremov D. (1970). Vozrast poimennoho aliuviia Dnestra po dannym palinolohicheskoho analiza [Age of floodplain alluvium of the Dniester river according to palynological analysis]. In Bull. Moscow. univ. Geography, 3, 102105. (In Russian).

Voropay L., Kunitsa M., Levitsky V. (1975). Pokhovani holotsenovi grunty zaplav serednioho Prydnistrovia ta yih paleogeografichne znachennia [Buried Holocene soils of the flood plains of middle Dniester river and the ir paleogeographical significance]. In Phys. geography and geomorphology., 14, 103-112. (In Ukrainian)

Hofstein I. (1958). K istorii doliny verkhnieho Dniestra [History of the Upper Dniester valley]. In Dokl. AN USSR., 120, 1, 159-161. (In Russian).

Hofstein I. (1962). Neotektonika i morfohenez Verkhnioho Prydnistrovia [Neotectonics and morphogenesis of the Upper Dniester area]. Kyiv: publ. AN URSR. 131 p. (In Ukrainian).

Demediuk N. (1974). Litolohicheskie osobenosti holotsenovych alliuvialnykh galiechnikov Predkarpattia [Lithological features of Holocene alluvial pebbles of Eastern Carpathian Foreland]. In Materialson the Quaternary period of Ukraine. IX Congress INQUA, 228-246. (In Russian).

Demedyuk N., Sokurov S. (1974). Anomalno-vysokiie moshchnosti alliuviia v predhornoi chasti doliny Dnestra i ispolzovaniiey ih pri poiskakh solei [Anomal ouslyhigh alluvial series in the foothills of the Dniester valley and its exploitation for searching salts]. In Materialson the Quaternary period of Ukraine. IX Congress INQUA., 259-265. (In Russian).

Kalynovych N. (2000). Palinolohichne doslidzhennia rozvytku roslynnoho pokryvu Verkhniodnistrovskoi rivnyny $\mathrm{v}$ holotseni [Palynological research of vegetation development of the Upper Dniester plain in the Holocene]. In Scientific Bulletin of UNFU., 10.3, 69-74. (In Ukrainian).

Kalynovych N., Harmata K. (2001). Rekonstruktsii istorii roslynnosti Verkhniodnistrovskoi rivnyny $\mathrm{v}$ holotseni na osnovi palinolohichnoho analizu torfovykh vidkladiv [Reconstruction of the history of vegetation of the Upper Dniester plain in the Holocene according to palynological analysis of peat deposits]. In Visnyk of the Lviv univ. Ser. Biology., 27, 78-88. (In Ukrainian).

Kalynovych N., Yatsyshyn A. (2001). Antropohenni zminy roslynnosti Pivnichnozakhidnoho Peredkarpattia v holotseni [Anthropogenic changes in the vegetation of the North-Western Precarpathians in the Holocene]. In Scienti ficherald of UzhNU. Ser. Biology, 10, 45-48. (In Ukrainian).

Palienko V. (1965). Vliianiie noveishykh dvizhenii zemnoi kory na stroenie holotsenovoi terrasy Verkhnioho Dnestra [Influence of the newest movements of 
the earth'scruston the structure of the Holocene terrace of the Upper Dniester river]. In Materials on the Quaternary period of Ukraine. VII Congress INQUA, 262-269. (In Russian).

Palienko V. (1969). O nekotorykh osobenostiakh geolohicheskoho stroieniia poimennykh terras Predkarpattia, obuslovlenykh neotektonicheskimi dvizheniiami [Some features of the geological structure of floodplain terraces Eastern Carpathian Foreland caused by neotectonic movements]. In Materials on the Quaternary period of Ukraine. VIII Congress INQUA, 198-209. (In Russian).

Palienko V. (1974). O tipakh holotsenovoho alliuviia doliny Dnestra [On the types of Holocene alluvium of the Dniester valley]. In Materials on the Quaternary period of Ukraine. IX Congress INQUA, 247-258. (In Russian).

Petrenko L., Tretiak P., Kovaliukh N. (1987). Geohronolohiia formirovaniia alliuvialnykh otlozhenii r. Dnestr v pozdniem holotsene [Geochronology of formation of alluvial deposits of the Dniester River in the late Holocene]. In Stratigraphy and correlation of marine and continental deposits of Ukraine, 78-84. (In Russian).

Raskatov G. (1954). K voprosu o drevniechetvertichnykh oliedienieniiakh zapadnykh oblastiei Ukrainy [About the question of ancient Quaternary glaciations of the western regions of Ukraine]. In Trudy geologich. Faculty of Voronezh. state un-ta, 31, 107-111. (In Russian).

Rudnytskyi,S. (1907). Znadoby do morfolohii pidkarpatskoho stochyshcha Dnistra [Morphology of the run of fof the Dniester riverin the Eastern Carpathian Foreland]. In Collection of the Math-NatureSection of NTSh, 11, 1-80. (In Ukrainian).

Tsys P. (1962). Geomorfolohiia URSR [Geomorphology of the USSR]. Lviv: Publ. Lviv univ., 223. (In Ukrainian).

Cherevko M. (1967). Materialy do istorii roslynnosti Prykarpattia v pislialiodovykovyi period [Materialsto the history of vegetation of Carpatian Foreland in the postglacial period]. In Visnyk of Lviv univ. Ser. Biology, 3, 102-111. (In Ukrainian)

Chumak N. M. (2013). Palaeoenvironments in the foothills of the Carpathian Mountains (the Gorgan region) during the Holocene (based on pollen data). (Candidate of Sciences' thesis). Taras Shevchenko National University of Kyiv, Kyiv. (In Ukrainian).

Chumak N. (2015). Rekonstruktsii roslynnoho pokryvu Prygorganskoho Peredkarpattia $\mathrm{u}$ piznioliodovykivi (za palinolohichnymy danymy torfovyshcha Pidluzhzhia) [Reconstruction of vegetation cover of the Gorgan`s Carpathian Foreland in late glacial (according to palynological data of Pidluzhzhia peat bog)]. In Visnyk of Lviv. univ. Ser Geography, 49, 333-340. (In Ukrainian).

Yatsyshyn A. M. (2001). Geomorphological structure of the Dniester valley with in the Eastern Carpathian Foreland. (Candidate of Sciences' thesis). Ivan Franko National University of Lviv, Lviv (In Ukrainian).

Yatsyshyn A. (2002). Novi dani pro budovu Verkhniodnistrovskoi ulohovyny [New data about the structure of the Upper Dniester basin]. In Regional ecological problems: Collection of sci. works of the Taras Shevchenko National University of Kyiv, 251-252. (In Ukrainian).

Yatsyshyn A., Bogucki A., Dmytruk R., Plotnikov A. (2010). Antropohenovi vidklady pivnichnoi chastyny Verkhniodnistrovskoi ulohovyny [Anthropogenic sediments of 
А.Яцишин, П. Гембіца Вивченість голоценового етапу...

ISSN 2519-2620. Проблеми геоморфології і палеогеографії...2020. Вип. 1 (11), 118-139

the north part Upper Dniester basin]. In Physical geography and geomorphology, 1(58), 177-188. (In Ukrainian).

Yatsyshyn A., Bogucki A., Holub B., Lanchont M., Tomeniuk O. (Eds.). (2011). Etapy morfohenezu pivnichno-zakhidnoi chastyny dolyny Dnistra [Stages of morphogenesis of the north-west part of the Dniester valley]. In Glyatsial and peryhlyatsial Ukrainian Carpathian Foreland: Coll. Science. works (XVII Ukrainian-Polish seminar. Sambir, September 15-18, 2011). 26-61. (In Ukrainian).

Budek, A., Jacyszyn, A., Starkel, L. (2000). Aluwia holoceńskie i ich relacja do faz osadniczych na Wysoczyźnie Samborskiej i w Kotlinie Górnego Dniestru [Holocene alluvium and its connections with the phases of sedimentation on the Sambir Uplandand the Upper Dniester Basin]. In Neolit i poczatki epoki brazu w Karpatach Polskich. Materialy z sesji naukowej (Krosno, 14-15 grudnia 2000 r.). Poland: Kraków, 241-249. (In Polish).

Budek A., Starkel L., Jacyšyn A. (2006) Strvjaž River valley. In Environment and man at the Carpathian foreland in the upper Dnister catchment from Neolithic to early mediaeval period / [Ed. by K. Harmata, J. Machnik, L. Starkel]. Krakow, 52-65.

Gębica P., Jacyšyn A., Krąpiec M. i in. (2007). Znaczenie kopalnych pni drzew i profili torfowych dla stratygrafii aluwiów i faz powodzi w dorzeczu górnego Dniestru [Significance of fossil trees and peats for stratigraphy of alluvial series and flood phases in the Upper Dniester basin]. In Krajobrazy dolin rzecznych: materiały polsko-ukraińskiej konferencij naukowej (IX seminarium krajobrazowe, 26-29. 05. 2007), Czerniowce-Sosnowiec-Czerniowce, 22-23. (In Polish).

Gębica P., Budek A., Starkel L. i in. (2008) Nowe wyniki badań nad stratygrafia aluwiów i holoceńską ewolucją doliny Strwiąża (Zachodnia Ukraina) [New results of studies of stratigraphy of alluvial series and Holocene evolution of the Strivigor valley (Western Ukraine)]. In Prace Komisji Paleogeografii Cwartorzędu PAU, 6, 93-103. (In Polish).

Gębica P., Starkel L., Jacyszyn A. i in. (2011) Ewolucja doliny Strwiąża w póżnym glacjale i holocenie na przedpolu Wschodnich Karpat (Zachodnia Ukraina) [Evolution of the Strivigor Valley in the Late Glacial and Holocene of the Eastern Carpathian Foreland (Western Ukraine)]. In Hliatsial i peryhliatsial Ukrainskoho Peredkarpattia : zb. nauk. prats (do KhVII ukr.-pol. seminaru. Sambir, 15-18 veresnia 2011 r). L'viv, 106-116. (In Polish).

Gębica P., Starkel L., Jacyszyn A., Krąpiec M. (2013) Medieval accumulation in the Upper Dniester river valley: The role of human impact and climate change in the Carpathian Foreland. In Quaternary International, 293, 207-218.

Gębica P., Jacyszyn A., Budek A., Czumak N. (2013) Ewolucja doliny Stryja i Dniestru w kotlinie Stryjsko-Źydaczowskiej w póżnym vistulianiee i holocenie [Evolution of the Stryi and Dniester valleys in the Stryi-Zhydachiv basin in the late glacial and Holocene]. In Lesovyi pokryv Pivnichnoho Prychornomor'ia : zb. nauk. prats (do XVIII ukr.-pol. seminaru. Roksolany, 8-13 veresnia 2013 r). Lublin, 241257. (In Polish).

Gębica P., Jacyszyn A. (2014) Młodoczwartorzędowa ewolucja doliny Dniestru i Stryja w Kotlinie Stryjsko-Źydaczowskiej (Wschodnie Przedkarpacie) [Late Pleistocene evolution of the Dniester and Stryi valleys in the Stryi-Zhydachiv basin (Eastern Carpathian Foreland)]. In Krajobrazy mtodoglacjalne ich morfogeneza 
teraźniejszość przyszlość: X Zjazd Geomorfologów Polskich (Toruń, 16-19 wrzesnia 2014 r.). Toruń, 41-42. (In Polish).

Gębica P., Jacyszyn A., Krąpiec M. et al. (2016) Stratigraphy of alluvia and phases of the Holocene floods in the valleys of the Eastern Carpathians foreland. Quaternary International, 415, 55-66.

Harmata K., Kalinovyč N., Budek A. et al. (2006). Mire and the Dnister valley near Majnyč. In Environment and man at the Carpathian foreland in the upper Dnister catchment from Neolithic to early mediaeval period / [Ed. by K. Harmata, J. Machnik, L. Starkel]. Krakow, 32-43.

Harmata K., Kalinovyč N., Budek A. et al. (2006). Environmental changes during the Holocene. In Environment and man at the Carpathian foreland in the upper Dnister catchment from Neolithic to early mediaeval period / [Ed. by K. Harmata, J. Machnik, L. Starkel]. Krakow, 66-81.

Harmata K., Madeja J., Kołaczek P. (2013). The locality Luka - palynological analysis. In Natural Environment and man on the Upper Dnister - region of the Halyč-Bukačivci Basin - in Prehistory and Early Mediaeval Period / [Ed. by K. Harmata, J. Machnik, M. Rybicka]. Kraków, 6, 42-49.

Harmata K., Szczepanek K., Cywa K. et al. (2013). The locality Cvitova palynological analysis. In Natural Environment and man on the Upper Dnisterregion of the Halyč-Bukačivci Basin - in Prehistory and Early Mediaeval Period I [Ed. by K. Harmata, J. Machnik, M. Rybicka]. Kraków, 6, 49-56.

Huhmann M., Kremenetski K. V., Hiller A., Brückner H. (2004). Late guaternary landscape evolution of the upper Dnister valley, western Ukraine. Paleogeography, Paleoclimatology, Paleoecology, 209, 51-71.

Jacyšyn A., Budek A., Kalinovyč N., Starkel L. (2006). Dnister River valley. In Environment and man at the Carpathian foreland in the upper Dnister catchment from Neolithic to early mediaeval period / [Ed. by K. Harmata, J. Machnik, L. Starkel]. Krakow, 21-31.

Kalinovyč N., Budek A., Starkel L. (2006). Peat-bog in the Bystrycia River valley near Ozerne (Now Luka). In Environment and man at the Carpathian foreland in the upper Dnister catchment from Neolithic to early mediaeval period / [Ed. by K. Harmata, J. Machnik, L. Starkel]. Krakow, 44-51.

Kostyniuk M. (1938). Analiza pylkowa dwuch torfowisk w okolicy Rudek i Sambora. [Pollen analysis of two peatlandson the outskirts of the Rudky and Sambir cities]. Kosmos, 63, 3, 393-412. (In Polish).

Łomnicki A. (1900). Atlas geologiczny Galicyi. Tekst do zeszytu 12. [Geological atlas of Galicia. Text to notebook 12]. Kraków, 80. (In Polish).

Starkel L., Gębica P., Budek A. et al. (2009). Evolution of the lower section of the Strvyaž riwer valley during the Holocene (foreland of the Eastern Carpathians). In Studia Geomorphologica Carpatho-Balcanica, 43, 5-37.

Teisseyre H. (1935). Czwartorzęd na predgórgu arkusza Stary Sambor [Anthropogenic on the foothills of the mapsheet Old Sambir]. In Rocz. Pol. tow. Geol., 8, 67-81. (In Polish).

Teisseyre H. (1938). Czwartorzęd na predhórgy arkuszy Sambor i Dobromil [Anthropogenic in the foothills of the mapsheet Sambir and Dobromil]. In Rocz. Pol. Tow. Geol., 13, 31-81. (In Polish). 